\title{
Identifikasi Daya Tampung Beban Pencemaran Air Kali Surabaya Segmen Jembatan Canggu- Tambangan Bambe dengan Pemodelan QUAL2Kw
}

\author{
Vivin Sintia Indriani, Wahyono Hadi, danAli Masduqi \\ Jurusan Teknik Lingkungan, Fakultas Teknik Sipil dan Perencanaan, Institut Teknologi Sepuluh \\ Nopember (ITS) \\ Jl. Arief Rahman Hakim, Surabaya 60111 Indonesia \\ e-mail:wahyono@enviro.its.ac.id, masduqi@its.ac.id
}

\begin{abstract}
Abstrak-Objek penelitian ini adalah Kali Surabaya. Sungai ini dimanfaatkan sebagai sumber air minum dan untuk proses produksi industri. Sungai ini menerima beban pencemaran dari limbah domestik, limbah pertanian dan limbah industri. Kali Surabaya diperlukan perhitungan daya tampung untuk mengetahui batas maksimum air limbah yang boleh dibuang ke sungai. Wilayah titik pantau pada penelitian ini terdapat 5 segmen. Parameter kualitas air yang dianalisa adalah $\mathrm{pH}$, suhu, DO, BOD, TSS, nitrat $\left(\mathrm{NO}_{3}\right)$, ammonium $\left(\mathrm{NH}_{4}\right)$ dan fosfat $\left(\mathrm{PO}_{4}\right)$. Analisis data menggunakan aplikasi program QUAL2Kw untuk menghitung beban pencemaran yang masuk ke Kali Surabaya. Pemodelan data dilakukan dengan trial and error hingga diperoleh hasil model yang sesuai (mendekati) kondisi yang sebenarnya. Setelah itu modeldiverifikasi, sehingga model dapat digunakan untuk menghitung berbagai macam skenario yang sudah ditentukan. Nilai daya tampung Kali Surabaya adalah $\mathrm{NH}_{4}$ berkisar antara $100 \mathrm{~kg} / \mathrm{hari}$ sampai $3563 \mathrm{~kg} / \mathrm{hari}$ dan $\mathrm{NO}_{3}$ berkisar antara $976 \mathrm{~kg} / \mathrm{hari}$ sampai $14306 \mathrm{~kg} / \mathrm{hari}$.
\end{abstract}

Kata kunci-Baku mutu, Daya tampung, Kali Surabaya, Kualitas air, QUAL2Kw

\section{PENDAHULUAN}

$\mathrm{K}$ ALI Surabaya adalah hilir Kali Brantas dengan panjang sekitar $42 \mathrm{~km}$ yang mengalir dari dam mlirip di mojokerto hingga pintu air Jagir. Kali Surabaya merupakan sumber konsumsi 2,7 juta jiwa masyarakat Surabaya yang dimanfaatkan sebagai sumber air minum dan untuk proses produksi industri. Pemanfaatan air minum sebesar 300 juta $\mathrm{m}^{3} /$ tahun dan sebesar 256 juta $\mathrm{m}^{3} /$ tahun sedangkan pemanfaatan air dari Kali Surabaya oleh industri mencapai 38 juta $\mathrm{m}^{3} /$ tahun dari total pemakaian sebesar 200 juta $\mathrm{m}^{3} /$ tahun.

Berdasarkan penelitian sebelumnya yang dilakukan oleh Suwari [4] dan Syafi'i [3], jumlah beban pencemaran air kali Surabaya sudah melebihi baku mutu yang sudah ditetapkan. Pencemar kali surabaya terutama bersumber dari limbah domestik, industri dan limbah pertanian [4].

Air merupakan sumber daya alam yang memenuhi hajat hidup orang banyak sehingga perlu dilindungi agar dapat tetap bermanfaat bagi hidup dan kehidupan manusia serta makhluk hidup lainnya. Untuk menjaga atau mencapai kualitas air sehingga dapat dimanfaatkan secara berkelanjutan sesuai dengan tingkat mutu air yang diinginkan, maka perlu upaya pelestarian dan atau pengendalian. Oleh karena itu, pada penelitian ini diidentifikasi daya tampung beban pencemaran terhadap kali Surabaya, sehingga dapat menentukan batas maksimum limbah yang dapat dimasukan ke dalam sungai agar sungai mampu memperbaiki kondisi kualitas airnya secara alami (self-purification).

Metode yang dapat digunakan dalam menetapkan daya tampung beban pencemaran air menurut Keputusan Menteri Negara Lingkungan Hidup Nomor 110 Tahun 2003 adalah metode komputasi. Metode komputasi adalah metode simulasi dengan bantuan program komputer, seperti model QUAL2Kw. Model QUAL2Kw sangat efesien serta mampu memodelkan kualitas air sungai dari hulu ke hilir [2]. Selain itu, Model QUAL2Kw dapat menstimulasi pengangkutan dan keberadaan pencemar di perairan. Model ini mensimulasikan sungai dalam bentuk satu dimensi dengan aliran berupa non-uniform, aliran tetap dan mempresentasikan sebuah sungai berdasarkan dampak dari dua sumber yaitu yang berasal dari point sources dan non-point sources [1].

Model QUAL2Kw dapat menstimulasi parameter $\mathrm{pH}$, alkalinitas, padatan tersuspensi anorganik, bakteri patogen, alga, suhu, CBOD cepat bereaksi, CBOD lambat bereaksi, Dissolved Oxygen (DO), fitoplankton, fosfor organik dan anorganik, nitrogen organik, $\mathrm{NH}_{4}$-Nitrogen, $\mathrm{NH}_{3}-\mathrm{Nitrogen}$, konduktivitas, bakteri pathogen dan alkalinitas [1].

Penelitian ini bertujuan untuk menidentifikasi beban pencemaran yang masuk ke Kali Surabaya dan menghitung daya tampung kali Surabaya dengan menggunakan program QUAL2Kw.

\section{URAIAN PENELITIAN}

Metode yang digunakan pada penelitian ini adalah sebagai berikut:

\section{A. Observasi Lapangan}

Observasi lapangan dilakukan untuk mengetahui titik pengambilan sampel dan sumber pencemar yang masuk ke kali Surabaya. 


\section{B. Penentuan Segmen atau Ruas}

Kali Surabaya dari hulu sampai hilir memiliki panjang 42,3 KM , namun panjang objek yang digunakan pada penelitian ini dari Jembatan Canggu-Tambangan Bambe memiliki panjang 27,78 KM. Penentuan segmen didasarkan atas segmen yang sudah digunakan pada data sekunder, masukan air limbahdan karakteristik fisik dan hidrolik Kali Surabaya, yaitu profil melintang sungai, debit air Kali Surabaya dan keberadaan anak sungai. Penentuan segmen dan titik koordinatnya dapat dilihat pada Tabel 1.

Tabel 1

Titik koordinat segmen kali Surabaya

\begin{tabular}{|c|c|c|}
\hline Nama Titik sampling & Selatan & Timur \\
\hline Jembatan Canggu & S $07^{\circ} 25^{\prime} 39.8^{\prime \prime}$ & E $112^{\circ} 28^{\prime} 25.3^{\prime \prime}$ \\
\hline Jembatan Perning & S $07^{\circ} 24^{\prime} 30.5^{\prime \prime}$ & E $112^{\circ} 29^{\prime} 34.1^{\prime \prime}$ \\
\hline Jembatan Legundi & S $07^{\circ} 23^{\prime} 13.6^{\prime \prime}$ & E $112^{\circ} 34^{\prime} 37.5^{\prime \prime}$ \\
\hline Tambangan Cangkir & S $07^{\circ} 21^{\prime} 57.2^{\prime \prime}$ & E $112^{\circ} 37^{\prime} 58.0^{\prime \prime}$ \\
\hline TambanganBambe & $\mathrm{S} 07^{\circ} 21^{\prime} 3,5^{\prime \prime}$ & E $11239^{\prime} 44,6^{\prime \prime}$ \\
\hline
\end{tabular}
Sumber: BLH, 2014

\section{Pengumpulan Data}

Pengumpulan data dibagi menjadi dua yaitu, data primer dan data sekunder. Data primer yang digunakan mecakup data parameter kualitas air yaitu $\mathrm{pH}, \mathrm{DO}, \mathrm{BOD}, \mathrm{NO}_{3}, \mathrm{NH}_{4}, \mathrm{PO}_{4}$, TSS, dan suhu serta debit sungai. Sedangkan data sekunder yang dikumpulkan yaitu peta Kali Surabaya, data klimatologi (temperatur udara dan kecepatan angin), data hidrolik (panjang sungai, lebar sungai, debit sungai, kecepatan aliran, dan kedalaman sungai), data kualitas air Kali Surabaya selama 5 tahun terakhir yaitu tahun 2011-2015, jumlah industri dan jumlah penduduk disekitar Kali Surabaya khusunya di sekitar segmen Jembatan Canggu-Tambangan Bambe.

\section{Pengambilan Sampel}

Debit air Kali Surabaya pada bulan Desember sampai bulan Mei, di beberapa titik pantau/pengukuran menunjukkan nilai yang besar, antara $50-100 \mathrm{~m}^{3} /$ detik. Pengambilan sampel didasarkan atas SNI 6989-57-2008 tentang metode pengambilan contoh yaitu sungai dengan debit antara 5 $\mathrm{m}^{3} /$ detik - $150 \mathrm{~m}^{3} /$ detik, contoh diambil pada dua titik masingmasing pada jarak 1/3 dan 2/3 lebar sungai pada kedalaman 0,5 kali kedalaman dari permukaan atau diambil dengan alat integrated sampler sehingga diperoleh contoh air dari permukaan sampai ke dasar secara merata kemudian dicampurkan.

\section{E. Pengggunaan QUAL2Kw}

Langkah awal yang dilakukan dalam pemodelan menggunakan QUAL2Kw adalah menginput data kualitas air, point source dan non-point source yang telah didapatkan ke dalam worksheet QUAL2Kw. Setelah itu, menentukan koefisien model dan dilakukan Run VBA. Model di-running berulang-ulang hingga diperoleh hasil model sesuai dengan kondisi sebenarnya. Penyesuaian model dilakukan dengan "trial and error" nilai koefisien model. Model yang sudah sesuai dapat diverifikasi dan digunakan untuk mensimulasi skenario yang sudah ditentukan. Skenario pada penelitian ini dapat dilihat pada Tabel 2.
Tabel 2

Teknik simulasi

\begin{tabular}{|c|c|c|c|c|}
\hline $\begin{array}{l}\text { Simu- } \\
\text { lasi }\end{array}$ & $\begin{array}{c}\text { Kondisi Air di } \\
\text { Hulu }\end{array}$ & $\begin{array}{c}\text { Data } \\
\text { sungai }\end{array}$ & $\begin{array}{c}\text { Sumber } \\
\text { Pencemar }\end{array}$ & $\begin{array}{c}\text { Kualitas } \\
\text { air sungai }\end{array}$ \\
\hline 1 & Existing & Existing & Existing & Model \\
\hline 2 & Existing & Existing & $\begin{array}{l}\text { Kondisi } \\
\text { Awal } \\
\text { (tidak ada } \\
\text { sumber } \\
\text { pencemar) }\end{array}$ & Model \\
\hline 3 & Existing & Existing & $\begin{array}{l}\text { Trial and } \\
\text { Error }\end{array}$ & $\begin{array}{c}\text { Baku } \\
\text { Mutu Air } \\
\text { Kelas II }\end{array}$ \\
\hline 4 & $\begin{array}{l}\text { Memenuhi } \\
\text { baku mutu } \\
\text { kelas II }\end{array}$ & Existing & Existing & Model \\
\hline 5 & $\begin{array}{l}\text { Memenuhi } \\
\text { baku mutu } \\
\text { kelas II }\end{array}$ & Existing & $\begin{array}{l}\text { Tidak ada } \\
\text { sumber } \\
\text { pencemar }\end{array}$ & Model \\
\hline 6 & $\begin{array}{l}\text { Memenuhi } \\
\text { baku mutu } \\
\text { kelas II }\end{array}$ & Existing & $\begin{array}{l}\text { Trial and } \\
\text { Error }\end{array}$ & $\begin{array}{c}\text { Baku } \\
\text { Mutu Air } \\
\text { Kelas II }\end{array}$ \\
\hline
\end{tabular}

Penjelasan Tabel 2 untuk keempat simulasi yang digunakan dalam penelitian ini adalah sebagai berikut:

1. Skenario 1

Pada skenario ini, data yang diinput dalam program adalah data existing pada kualitas air dari hulu. Data diperoleh dari sumber pencemar tak tentu dan sumber pencemar tertentu. Sumber pencemar tak tentu berasal dari limbah rumah tangga yang masuk ke sunga yang diestimasikan dari jumlah jumlah penduduk yang dikalikan dengan faktor emisi. Sedangkan sumber pencemar tertentu berasal dari industri (beban limbah berasal dari efluen industri yang mengarah langsung ke sungai). Beban limbah dari saluran drainase dan lainnya diasumsikan sebagai sumber tak tentu.

\section{Skenario 2}

Pada skenario ini kualitas air di hulu Kali Surabaya sesuai dengan data existing. Sementara itu, diasumsikan tidak ada sumber pencemaran yang masuk pada Kali Surabaya, baik dari limbah industri maupun limbah domestik.

\section{Skenario 3}

Pada skenario ini kualitas air di hulu Kali Surabaya sesuai dengan baku mutu air kelas II pada PP No. 82 Tahun 2001.Skenario ini dilakukan dengan menggunakan "trial and error". Skenario ini digunakan untuk menghitung daya tampung sungai.

\section{Skenario 4}

Pada skenario inisama dengan skenario 1, namunkualitas air di hulu Kali Surabaya dianggap sesuai dengan baku mutu air kelas II pada PP No. 82 Tahun 2001. Skenario ini dimaksudkan untuk menghilangkan pemcemaran yang terjadi pada sungai atau air yang masuk ke Kali Surabaya yaitu air yang masuk dari DAS Brantas.

\section{Skenario 5}

Pada skenario ini sama dengan skenario 2, namun kualitas air di hulu Kali Surabaya dianggap sesuai dengan baku mutu air kelas II pada PP No. 82 Tahun 2001.

6. Skenario 6

Pada skenario ini sama dengan skenario 3, namun kualitas air di hulu Kali Surabaya dianggap sesuai dengan baku mutu air kelas II pada PP No. 82 Tahun 2001 
Penentuan daya tampung menggunakan skenario 2 (tanpa pencemar) dan skenario 3 (beban pencemar maksimum). Daya tampung merupakan selisih beban pencemar penuh dengan tanpa pencemar.

\section{ANALISA DAN PEMBAHASAN}

\section{A. Segmentasi Sungai}

Kali Surabaya mempunyai panjang 42,3 KM, namun pada penelitian ini hanya dibatasi sampai Tambangan Cangkir. Segmen yang digunakan untuk kebutuhan pembentukan model dibagi menjadi beberapa segmen yang dimulai dari kilometer ke-27,78 (Jembatan Canggu) sampai kilometer ke-0 (Tambangan Bambe).

1. Segmen $1-2(3,78 \mathrm{~km})$

Segmen awal atau hulu dari sungai pada kilometer 27,78 hingga kilometer 24. Segmen 1-2 dibagi berdasarkan karakteristik kualitas air sungai dengan masukan limbah industri, limbah pertanian, dan limbah domestik serta dengan adanya perubahan hidrolik sungai.

2. Segmen 2-3 (11,9 km)

Segmen 2-3 dari sungai pada kilometer 24 hingga kilometer 12,10. Segmen 2-3 dibagi berdasarkan karakteristik kualitas air sungai setelah masukan limbah industri, limbah pertanian dan limbah domestik.

3. Segmen $3-4(8,5 \mathrm{~km})$

Segmen 3-4 dari sungai pada kilometer 12,10 hingga kilometer3,6. Segmen 3-4 dibagi berdasarkan karakteristik kualitas air sungai adanya masukan limbah domestik dan limbah industri.

4. Segmen 4-5 (3,6 km)

Segmen 4-5 dari sungai pada kilometer 3,6 hingga kilometer 0. Segmen 4-5 dibagi berdasarkan karakteristik kualitas air sungai adanya masukan limbah domestik, limbah industri dan anak sungai.

\section{B. Kualitas Air Kali Surabaya}

Data kualitas air sumber pencemar industri didapatkan dari hasil pemantauan kualitas air yang dilakukan oleh BLH Provinsi Jatim yang dilakukan setiap bulan sekali. Data kualitas air Kali Surabaya selengkapnya dapat dilihat pada tabel 3 .

Tabel 3

Kualitas air Kali Surabaya tahun 2011-2015

\begin{tabular}{cccccccc}
\hline \hline Lokasi & $\begin{array}{c}\mathrm{TSS} \\
(\mathrm{mg} / \mathrm{l})\end{array}$ & $\begin{array}{c}\mathrm{DO} \\
(\mathrm{mg} / \mathrm{l})\end{array}$ & $\begin{array}{c}\mathrm{BOD}_{5} \\
(\mathrm{mg} / \mathrm{l})\end{array}$ & $\begin{array}{c}\mathrm{NH}_{4} \\
(\mathrm{mg} / \mathrm{l})\end{array}$ & $\begin{array}{c}\mathrm{NO}_{3} \\
(\mathrm{mg} / \mathrm{l})\end{array}$ & $\begin{array}{c}\mathrm{PO}_{4} \\
(\mathrm{mg} / \mathrm{l})\end{array}$ & $\mathrm{pH}$ \\
\hline $\begin{array}{c}\text { Jembatan } \\
\text { Canggu }\end{array}$ & 115 & 6.75 & 4.41 & 0.25 & 2.52 & 1.42 & 7.5 \\
$\begin{array}{c}\text { Jembatan } \\
\text { Perning }\end{array}$ & 141 & 6.70 & 4.52 & 0.18 & 2.39 & 1.32 & 7.2 \\
$\begin{array}{c}\text { Jembatan } \\
\text { Legundi }\end{array}$ & 184 & 6.65 & 5.20 & 0.14 & 2.37 & 1.19 & 7.2 \\
$\begin{array}{c}\text { Tambangan } \\
\text { Cangkir }\end{array}$ & 140 & 6.40 & 5.48 & 0.24 & 1.95 & 1.15 & 7.1 \\
$\begin{array}{c}\text { Tambangan } \\
\text { Bambe }\end{array}$ & 123 & 5.56 & 5.41 & 0.33 & 1.93 & 1.33 & 6.9 \\
\hline \hline
\end{tabular}

Sumber: Diolah dari data hasil pemantauan BLH tahun 2011-2015

\section{Pembangunan Model}

Pembangunan model terdapat dua tahap yaitu pembangunan parameter hidrolik dan kualitas air. Parameter hidrolik yang dimodelkan adalah kedalaman sungai, kecepatan aliran sungai dan debit. Sedangkan untuk parameter kualitas air yaitu parameter suhu, $\mathrm{pH}$, ammonium, fosfat, nitrat, $\mathrm{BOD}, \mathrm{DO}$, dan TSS. Pembangunan model diawali dengan menginput data pada whorksheet yang terdapat pada program QUAL2Kw. Kemudian di-klik tombol "Run VBA". Data yang telah di-input akan membentuk model berupa grafik. Model dikatakan sudah benar apabila telah mendekati nilai pada data pemantauan (titik hitam). Apabila model belum terbentuk maka dilakukan trial and error. Hasil pembangunan model untuk parameter hidrolik dapat dilihat pada Gambar 1 Sampai Gambar 3.

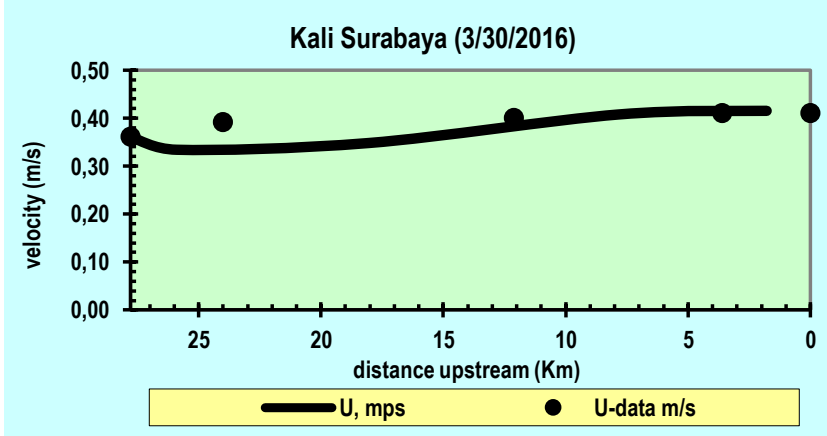

Gambar 1Perbandingan model dan data untuk parameter kecepatan aliran

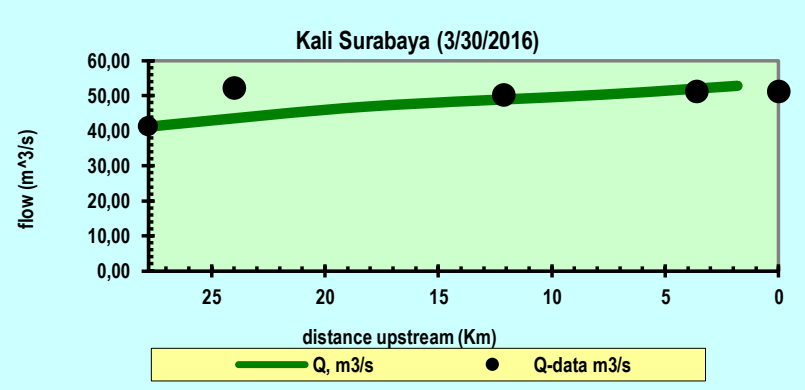

Gambar 2 Perbandingan model dan data untuk parameter debit

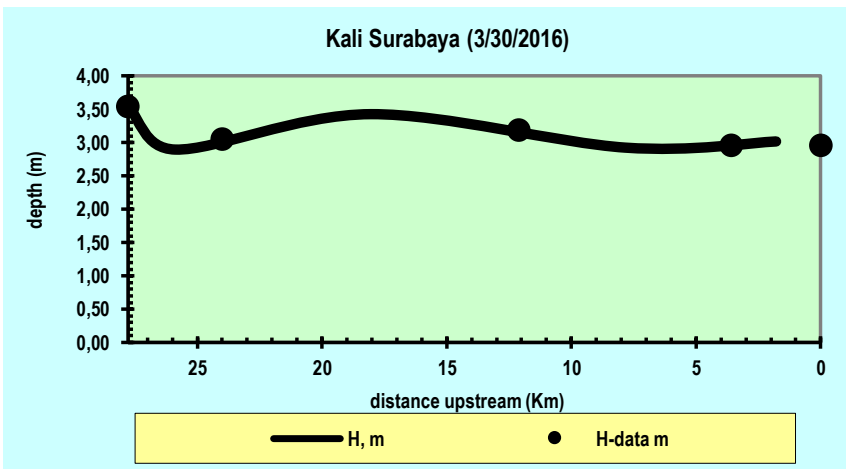

Gambar 3 Perbandingan model dan data untuk parameter kedalaman

\section{Verifikasi Model}

Verifikasi model dimaksudkan untuk membuat model yang mendekati data. Verifikasi model perlu dilakukan karena adanya variasi data pada waktu yang berbeda, baik pada kualitas air sungai dan kualitas air limbah. Verifikasi dilakukan sama dengan pembentukan model, namun data yang digunakan berbeda. Setelah model diverifikasi maka model 
dapat digunakan untuk mensimulasi skenario yang terdapat pada Tabel 2.

\section{E. Simulasi Kualitas Air}

Model kualitas air Kali Surabaya yang telah didapatkan kemudian digunakan untuk melakukan simulasi skenario 1 sampai skenario 6. Skenario yang digunakan untuk menghitung daya tampung Kali Surabaya adalah skenario yang kondisi di hulu sesuai dengan kondisi existing yaitu skenario 2 dan skenario 3. Skenario 2 menyatakan kondisi kali Surabaya tanpa pencemar sedangkan skenario 3 menyatakan kondisi kali Surabaya dengan beban pencemaran penuh (sesuai dengan baku mutu badan air kelas II). Perhitungan beban pencemaran yaitu dengan cara mengalikan debit inflow dengan konsentrasi yang terdapat pada worksheet source summary. Beban pencemaran skenario 2 dapat dilihat pada tabel 4 sedangkan beban pencemaran untuk skenario 3 dapat dilihat pada tabel 5 .

Tabel 4

Beban pencemaran skenario 2

\begin{tabular}{|c|c|c|c|c|c|c|}
\hline Reach & KM & $\begin{array}{l}\text { TSS } \\
\mathrm{kg} / \\
\text { hari }\end{array}$ & $\begin{array}{c}\text { BOD } \\
\mathrm{kg} / \\
\text { hari }\end{array}$ & $\begin{array}{l}\mathrm{NH}_{4} \\
\mathrm{~kg} / \\
\text { hari }\end{array}$ & $\begin{array}{l}\mathrm{NO}_{3} \\
\mathrm{~kg} / \\
\text { hari }\end{array}$ & $\begin{array}{c}\mathrm{PO}_{4} \\
\mathrm{~kg} / \\
\text { hari }\end{array}$ \\
\hline $\begin{array}{c}\text { Segmen } \\
1-2\end{array}$ & $24-27.78$ & 0 & 0 & 0 & 20 & 0 \\
\hline $\begin{array}{c}\text { Segmen } \\
2-3\end{array}$ & $12.1-24$ & 0 & 0 & 0 & 6 & 0 \\
\hline $\begin{array}{l}\text { Segmen } \\
3-4\end{array}$ & $3.6-12.10$ & 0 & 0 & 0 & 6 & 0 \\
\hline $\begin{array}{c}\text { Segmen } \\
4-5\end{array}$ & $0-3.6$ & 3306 & 207 & 35 & 75 & 14 \\
\hline
\end{tabular}

Tabel 5

Beban pencemaran untuk skenario 3

\begin{tabular}{ccccccc}
\hline \hline Reach & $\mathrm{KM}$ & $\begin{array}{c}\mathrm{TSS} \\
\mathrm{kg} / \\
\text { hari }\end{array}$ & $\begin{array}{c}\mathrm{BOD} \\
\mathrm{kg} / \\
\text { hari }\end{array}$ & $\begin{array}{c}\mathrm{NH}_{4} \\
\mathrm{~kg} / \\
\text { hari }\end{array}$ & $\begin{array}{c}\mathrm{NO}_{3} \\
\mathrm{~kg} / \\
\text { hari }\end{array}$ & $\begin{array}{c}\mathrm{PO}_{4} \\
\mathrm{~kg} / \\
\text { hari }\end{array}$ \\
\hline $\begin{array}{c}\text { Segmen } \\
1-2\end{array}$ & $24-27.78$ & 0 & 0 & 380 & 14326 & 0 \\
$\begin{array}{c}\text { Segmen } \\
2-3\end{array}$ & $12.1-24$ & 0 & 0 & 3563 & 4047 & 0 \\
$\begin{array}{c}\text { Segmen } \\
3-4\end{array}$ & $3.6-12.10$ & 0 & 0 & 100 & 3612 & 0 \\
$\begin{array}{c}\text { Segmen } \\
4-5\end{array}$ & $0-3.6$ & 3306 & 207 & 487 & 1050 & 14 \\
\hline \hline
\end{tabular}

\section{F. Daya tampung}

Penentuan daya tampung merupakan perhitungan selisih antara kondisi sungai dengan beban penuh (skenario 3) dan kondisi sungai dengan tanpa pencemaran (skenario 2). Hasil perhitungan daya tampung dapat dilihat pada tabel 6 .

Tabel 6

Daya tampung kali surabaya

\begin{tabular}{ccccccc}
\hline \multicolumn{7}{c}{ Daya tampung kali surabaya } \\
Reach & $\mathrm{KM}$ & $\begin{array}{c}\mathrm{TSS} \\
\mathrm{kg} / \\
\mathrm{hari}\end{array}$ & $\begin{array}{c}\mathrm{BOD} \\
\mathrm{kg} / \\
\mathrm{hari}\end{array}$ & $\begin{array}{c}\mathrm{NH}_{4} \\
\mathrm{~kg} / \\
\mathrm{hari}\end{array}$ & $\begin{array}{c}\mathrm{NO}_{3} \\
\mathrm{~kg} / \\
\mathrm{hari}\end{array}$ & $\begin{array}{c}\mathrm{PO}_{4} \\
\mathrm{~kg} / \\
\text { hari }\end{array}$ \\
\hline $\begin{array}{c}\text { Segmen } \\
1-2 \\
\text { Segmen } \\
2-3\end{array}$ & $24-27.78$ & 0 & 0 & 380 & 14306 & 0 \\
$\begin{array}{c}\text { Segmen } \\
3-4\end{array}$ & $3.6-12.10$ & 0 & 0 & 100 & 3606 & 0 \\
$\begin{array}{c}\text { Segmen } \\
4-5\end{array}$ & $0-3.6$ & 0 & 0 & 453 & 976 & 0 \\
\hline \hline
\end{tabular}

Hasil perhitungan daya tampung pada Tabel 6 menunjukkan bahwa daya tampung beban pencemaran untuk parameter ammonium dan nitrat masih banyak sedangkan untuk parameter TSS, BOD, dan Fosfat sudah tidak ada.

\section{G. Penurunan Beban}

Penurunan beban pencemaran dimaksudkan untuk menurunkan beban pencemaran yang masuk ke Kali Surabaya sehingga kualitas air kali Surabaya masih memenuhi baku mutu badan air kelas II. Perhitungan penurunan didapatkan dengan menghitung selisih antara skenario 1 dengan daya tampung. Hasil perhitungan beban penurunan beban pencemaran dapat dilihat pada tabel7.Hasil perhitungan untuk beberapa segmen menunjukkan nilai positif. Hal ini bearti penurunan beban pencemaran pada segmen tersebut masih diperlukan sedangkan nilai nol menunjukkan bahwa pada segmen tersebut tidak perlu dilakukan penurunan.

Tabel 7

Penurunan beban pencemaran pada setiap segmen

\begin{tabular}{ccccccc}
\hline \hline Reach & $\mathrm{KM}$ & $\mathrm{TSS}$ & $\mathrm{BOD}$ & $\mathrm{NH}_{4}$ & $\mathrm{NO}_{3}$ & $\mathrm{PO}_{4}$ \\
$\mathrm{mgD} / \mathrm{L}$ & $\begin{array}{c}\mathrm{mgO} 2 / \\
\mathrm{LgN} /\end{array}$ & $\begin{array}{c}\mathrm{ugN} / \\
\mathrm{L}\end{array}$ & $\begin{array}{c}\mathrm{ugP} / \\
\mathrm{L}\end{array}$ \\
\hline $\begin{array}{c}\text { Segmen } 1 \\
-2 \\
\begin{array}{c}\text { Segmen } \\
2-3\end{array}\end{array}$ & $24-27.78$ & 10143 & 1980 & 0 & 0 & 25 \\
$\begin{array}{c}\text { Segmen } \\
3-4\end{array}$ & $3.6-12.10$ & 180013 & 6099 & 0 & 0 & 98 \\
$\begin{array}{c}\text { Segmen } 4 \\
-5\end{array}$ & $0-3.6$ & 85392 & 4824 & 0 & 0 & 86 \\
\hline \hline
\end{tabular}

\section{KESIMPULAN}

Berdasarkan hasil pemodelan dengan menggunakan program QUAL2Kw, daya tamping Kali Surabaya untuk setiap segmen adalah sebagai berikut:

- Parameter $\mathrm{NH}_{4}$

- Jembatan Canggu - Jembatan Perning $=380 \mathrm{~kg} / \mathrm{hari}$

- Jembatan Perning - Jembatan Legundi $=3563 \mathrm{~kg} / \mathrm{hari}$

- Jembatan Legundi - Tambangan Cangkir $=100 \mathrm{~kg} / \mathrm{hari}$

- Tambangan Cangkir - Tambangan Bambe $=453 \mathrm{~kg} / \mathrm{hari}$

- Parameter $\mathrm{NO}_{3}$

- Jembatan Canggu - Jembatan Perning = 14306 kg/hari

- Jembatan Perning - Jembatan Legundi $=4041 \mathrm{~kg} / \mathrm{hari}$

- Jembatan Legundi - Tambangan Cangkir $=3606 \mathrm{~kg} / \mathrm{hari}$

- Tambangan Cangkir - Tambangan Bambe $=976 \mathrm{~kg} / \mathrm{hari}$

\section{UCAPAN TERIMA KASIH}

Penulis mengucapkan terimakasih kepada Dosen pembimbing Tugas Akhir, Bapak Wahyono Hadi. Serta dosen penguji Bapak Ali Masduqi, Bapak Bowo Joko Marsono dan Bapak Sarwoko Mangkoedihardjo atas segala ilmu, pengarahan, kesediaan dan kesabaran dalam membimbing penulis. Penulis juga mengucapkan terimakasih kepada Dosen Wali, Bapak Mohammad Razif atas segala dukungan, do'a dan pengarahan yang telah diberikan. Ketua Jurusan Teknik Lingkungan atas kesempatan yang diberikan kepada penulis untuk melaksanakan Tugas Akhir.

Penulis juga mengucapkan terima kasih kepada Direktorat Pendidikan Tinggi, Departemen Pendidikan dan Kebudayaan 
Republik Indonesia yang telah memberikan dukungan

finansial melalui Beasiswa Bidik Misi tahun 2012-2016. Penulis juga mengucapkan terimakasih kepada kedua orang tua yang senantiasa mendukung dan memberikan do'a dan kepada Bapak Helmi yang telah membimbing dan mendukung penulis serta memberikan dukungan finansial terhadap penelitian ini.

\section{DAFTAR PUSTAKA}

[1] Pelletier, Gregory J., Steven C. Chapra, dan Hua Tao. 2006. "QUAL2Kw - A Framework for Modeling Water Quality in Streams and Rivers Using a Genetic Algorithm for Calibration". Environmental Modelling and Software. Vol 21 (2006) 419e425.

[2] Rusnugroho,A., Ali masduqi. 2012. "Penentuan Daya Tampung Beban Pencemaran Kali Madiun (Segmen Wilayah Kota Madiun) Menggunakan Qual2kw". Scientific Conference of Environmental Technology Ix-2012. ISBN XXXX-XXXX

[3] Syafi'i, M dan Ali Masduqi. 2011. Aplikasi Model Simulasi Komputer QUAL2Kw Pada Studi Pemodelan Kualitas Air Kali Surabaya.Surabaya: Jurusan Teknik Lingkungan, Fakultas Teknik Sipil dan Perencanaan, Institut Teknologi Sepuluh Nopember Surabaya.

[4] Suwari, Etty Riani, Bambang Pramudya, Dan Ita Djuwita. 2011a. "Model Dinamik Pengendalian Pencemaran Air Kali Surabaya". Jurnal bumi lestari. 11(2). 234-248. 